\title{
„Pojęciownik" Vladimira Bitijego
}

V. Biti, Poimovnik suvremene knji-

Žec teorije, Zagreb 1997, s. 479

\section{Przedsięwzięcie jednego człowieka}

Slownik - niech zostanie tymczasem ta nazwa - chorwackiego teoretyka, Vladimira Bitijego ${ }^{1}$, jest próbą ujęcia przemian i przewartościowań, jakie dokonały się w dziedzinie teorii literatury przede wszystkim w wieku XX. Założenie to iście heroiczne, zwłaszcza jeśli uświadomić sobie, że na okładce książki widnieje nazwisko tylko jednego autora, i nie jest to nazwisko redaktora, jak zwykle bywa przy tego typu publikacjach. Pomyslodawcą książki nie był wprawdzie sam Biti, bo propozycja wyszła od redaktorki wydawnictwa "Matica hrvatska”, gdzie opublikowane zostały później oba jej wydania $(1997,2000)$, od początku do końca mamy jednak do czynienia $\mathrm{z}$ pracą jednego czlowieka.

(17) Pierwsze hasła, pogrupowane w bloki tematyczne, zaczęly ukazywać się w polowie lat dziewięćdziesiątych na łamach „Republiki” (jednego z najważniejszych chorwackich czasopism poświęconych literaturze). Pierwsze wydanie z 1997 roku przyjęte zostało przez rodzimych recenzentów entuzjastycznie; publikację uznano nawet za jedno z najważniejszych wydarzeń teoretycznoliterackich ostatnich dziesięcioleci, a autorowi przyznane zostały prestiżowe wyróżnienia i nagrody (recenzję z pierwszego wydania zamieściły również „Teksty Drugie”)2. Praca nad słownikiem nie została jednak przerwana, w „Republice” znów zaczęły pojawiać się nowe hasła. Drugie wydanie $z$ roku 2000, rozszerzone i pod zmienionym tytułem, przyjęto równie entuzjastycznie, a proces przemiany sposobu myślenia o teorii literatury, zapoczątkowany w Chorwacji dzięki pracy Bitijego, stał się nieodwracalny. W 2001 ukazało się tłumaczenie na język niemiccki³.

Biti (ur. 1952, w Nowym Sadzie) związany jest z uniwersytetem w Zagrzebiu. Od lat kieruje katedrą teorii literatury, a jego wykłady („Jak czytać tekst literacki?”) cieszą się wśród studentów wielkim zainteresowaniem. Jest autorem sześciu ksią$\dot{z}^{4} k^{4}$, redaktorem i współredaktorem antologii tekstów dotyczących teorii literatury. Od 1996 r. przewodniczy Chorwackiemu Towarzystwu Semiotycznemu, jest takze czlonkiem International Association for Semiotic Studies oraz International Compa-

1 V. Biti, Pojmounik suuremene knjižee teorije, Zagreb 1997, s. 479; oraz drugie wydanie o zmienionym tytule: Pojmounik suuremene knjižeune i kulturne teorije, Zagreb 2000, s. 695. Dalej jako PI i PlI.

2 M. Dąbrowska-Partyka, W horyzoncie teorii literackiej, „Teksty Drugie” 2001, nr 5, s. $111-115$.

3 V. Biti, Literatur- und Kulturtheorie. Ein Handbuch gegenwärtiger Begriffe, Hamburg 2001.

- Vladimir Biti jest autorem prac: Bajka i predaja (1981); Interes pripovijednog tchsta (1987); Pripitomljavanje drugog (1989); Upletanje nerečenog. Knjizeunost/povijest/teorija (1994); Strano tijelo prilpovijesti: Etičko-politička granica identiteta (2000), także w języku niemieckim: - Dishurs der Schwelle. Aspekte der krotischen Gegenwartsprosa (1996) oraz redaktorem antologii: Bahtin $i$ drugi (1992); Suvremena teorija pripovijedanja (1992); Trag i razlika (1995). 
rative Literature Association. Jego zainteresowania badawcze wydają się więc ukierunkowanie semiotyczne, trudno jednak u Bitijego o jakieś deklaracje dotyczące wyznawanej metody.

Decydując się na formę słownika, Biti przyjmuje rolę bibliofila bądź polihistora, w których istnienie dawno już przestaliśmy wierzyć, co najwyżej traktując ich jako metafory modernistycznych poszukiwaczy prawdy. Biti wybiera formę naukowego dyskursu, najczystszego jaki można sobie wyobrazić: formę encyklopedii, książki (chciałoby się napisać lssięgi), w której można znaleźć odpowiedzi na wszystkie pytania, cytując ją jako instancję uprawomocniającą. Jednocześnie wszakże uprzedza czytelnika o wpływach, jakie na tekst mogły mieć miejsce, czas i okoliczności powstania, nie ukrywa własnej perspektywy ani preferencji teoretycznych i światopoglądowych (uprzedza o tym we wstępie, PI, s. V-VI). Te zależności są wręcz dla niego koniecznymi warunkami stworzenia nie tylko takiego tekstu, jaki zamierzył, ale generalnie nieuniknionymi uwarunkowaniami, kióre towarzyszq wszelkim wypowiedziom o literaturze ${ }^{5}$. Choć więc mogloby się wydawać, że wybór formy leksykonu mial za zadanie przezwyciężyć te uwarunkowania, okazuje się, że był zabiegiem formalnym. Zarazem, trzeba powtórzyć, iż autor wcale nie deklaruje się jako przedstawiciel jakiejś metodologii czy szkoły.

-olonzecz w tym, że konwencja słownika zostaje przez Bitijego przenicowana na wskroś i wszerz, w rezultacie świadomego podszycia się autora-indywidualisty pod neutralnego polihistora. Świadomość zaś ograniczeń, jakie wynikają z autorskiej perspektywy, stwarza dogodny punkt wyjścia do rozważenia problemu możliwości istnienia uprawomocnionego metajęzyka. Przedmowę do drugiego wydania kończy więc Biti cytatem z Wlasnego pokoju Wirgini Woolf, ukazującym iluzortyczność dotarcia do prawdy, zwłaszcza jeśli przedmiot poszukiwań nie jest dany, a jeśli jest, to pełen sprzeczności i niejasności. A taka jest właśnie współczesna teoria literatury i kultury.

Te przejawy „skromności” można oczywiście uznać za zadośćuczynienie konwencji. Jednak wszystkie oznaki pokory wobec uwikłań, jakie towarzyszą współczesnej teorii literatury, mają uczulić czytelnika, że nie ma do czynienia z dzielem absolutnym, skończonym i definitywnym, które $w$ dodatku byłoby nieświadome własnej ograniczoności.

\section{Metoda błądzenia}

Obrazu autora dopetnia pozycja „autsajdera”, jaką zdaje się on zajmować w świecie teorii. Zagrzeb nie należy do liczących się ośrodków dwudziestowiecznego literaturoznawstwa. W postawie Bitijego nie ma jednak niczego z zachowania dalekiego kuzyna z prowincji, który wpada w entuzjazm bądź przestrach na widok nowości (nadążanie za nowinkami dla badacza w Jugosławii, a później i w Chorwacji, acz zaprzątniętej w ostatnim dziesięcioleciu polityką, nie było aż tak trudne jak w PRL). Przyjmując pozycję nieprzynależności do żadnej z "koterii” teoretycznoliterackich oraz instytucjonalnej marginesowości, zyskuje lepszy ogląd problemów, niż reprezentant lub wyznawca określonej formacji intelektualnej.

Lubs 5 Cytat pochodzący z rozmowy T. Brleka z V. Bitim, przeprowadzonej dla Trzeciego Programu Chorwackiego Radia i opublikowanej na łamach dwutygodnika; Metoda urludanja, „Zarez”, nr 52. Dalej jako MV. 
Biti porusza się swobodnie po obszarach wszystkich najważniejszych tradycji literaturoznawczych - niemieckiej, francuskiej i angloamerykańskiej, nieobcy jest mu dorobek z obszarów słowiańskich (to właśnie dzięki jego wczesnym pracom przeszczepiona została na grunt chorwacki koncepcja Bachtina; w leksykonie pojawiają się także polskie nazwiska) czy ogólnie wschodnioeuropejskich. Biti nie zapomina także o chorwackich osiągnięciach w tej dziedzinie; zagrzebska szkoła stylistyki rozwijająca pod wpływem francuskiego strukturalizmu i jej „formacje stylistyczne” także zostały odnotowane w leksykonie. O tym zaś, jak uważnym obserwatorem współczesnej sceny teoretycznej jest Biti, świadczyć może drugie wydanie leksykonu (zaledwie po trzech latach od pierwszego, grubsze o dwieście stron), poszerzone nie tylko o nowe hasła $\mathrm{z}$ dziedziny teorii kultury (o czym mówi zmieniony tytuł), ale również uzupełnienia poszczególnych haseł o najnowsze publikacje.

Wybierając pozycję obserwatora, Biti doskonale ją wykorzystuje. Jak sam przyznaje w rozmowie opublikowanej na lamach jednego $z$ chorwackich dwutygodników kulturalnych, w ciągu swojej badawczej działalności zdołał sobie wyrobić swoją własną metodę działania - metodę błądzenia czy może raczej błąkania się, która zapewnia swobodę przemieszczania się po różnych przestrzeniach.

Wyobrażam sobie, że poprzez przechodzenie $z$ jednej przestrzeni w druga uda mi się dostrzec jakieś ślepe punkty różnych teoretycznych horyzontów - powiada", by zaraz zastrzec: „ale to w żaden sposób nie wyklucza istnienia ślepych zaułków mojego własnego horyzontu, który wystawiony zostaje na konfrontację $\mathrm{z}$ innymi poglądami. [MV]

Takie błąkanie się pozwala śledzić zagadnienie w różnych kontekstach, testować je na różne sposoby, zakradać się z wielu stron, zapewnia wielowymiarowość, choć nie gwarantuje osiągnięcia prawdy.

Kiedy znów rozmówca Bitijego sugeruje, że taka marginesowość to raczej wybór kategorii percepcji, odpowiada:

Człowiek może starać się utrzymać swoją marginesową pozycję jako perspektywę teoretyczną, jako kategorię percepcji, ale może mu się przydarzyć, że kultura i naukowy margines, na którym żyje, determinują go w sposób, jakiego się nie spodziewa i nie może sobie uświadomić. Ja w każdym razie nie jestem pewny, czy to się w moim przypadku nie zdarzylo! (...) Nigdy marginesowość nie może być zamierzona ani nie może być całkowicie teoretycznie wyartykułowana, ona zawsze jest rezultatem usytuowania teoretyka w instytucyjnym, kulturalnym, ideologicznym, ekonomicznym, jakimkolwiek chcecie, systemie. Pytanie brzmi, koniec końców, co znaczy w ogóle w dzisiejszym świecie margines i jak można go definiować, ponieważ świat idei zamienił się $\mathbf{w}$ wieloogniskową konstelację $z$ wieloma różnymi centrami; nie istnieją już jasno rozgraniczone centra i peryferie, one się w wieloraki sposób wzajemnie determinują, więc pytanie dotyczy tego, kto i skąd mówi. [MV]

Kolejną sprawą jest kondycja teorii literatury w samej Chorwacji. Punktem wyjścia i odniesienia Bitijego była wspomniana szkoła stylistyki. Z nią właśnie przyszło mu się rozliczać i wobec niej ustosunkowywać w poszukiwaniu własnego miejsca.

\section{Pojęciownik współczesnej teorii literackiej i kulturowej}

Już w samym tytule książki Bitijego kryje się swojego rodzaju manifest teoretyczny, dlatego też właściwe jego przetłumaczenie staje się kwestią zasadniczą. Przede wszystkim zasluguje na wyjaśnienia sama nazwa gatunkowa pojmounik. 
Polski dosłowny przekład tego chorwackiego neologizmu mogłby, z pewnym ryzykiem, brzmieć pojeciownik. Dotychczas używane wymiennie określenia "słownik” i "leksykon" nie są najwłaściwsze, podobnie jak „słownik terminologiczny" czy "słownik terminów". Wszystkie one sugerują istnienie wspólnego języka teoretycznego, spójnego systemu definicji, niezmienności i systemowości. Przekreślałyby też dotychczas przytoczone za Bitim argumenty na rzecz niemożności czystego metateoretycznego języka i negację wszystkich wątpliwości, jakie jego przedsięwzięciu towarzyszyły.

Aftho Biorąc pod uwagę kontekst kroatystyczny, tzn. mając w pamięci książkę Joanny Rapackiej (stąd w ogóle przywoływane określenie „leksykonu”) Leksykon tradycji chorwackich (1997), zapytać można - dlaczego nie „leksykon”? Praca Rapackiej zdaje się bowiem doskonale realizować tę samą, co i Bitiego, zasadę poruszania się po pewnej przestrzeni, w tym wypadku historyczno-mitologicznej, poprzez obserwację ważnych dia niej pojęć, konstrukcji ideowych, fantazmatów. Jednak nazwa „leksykon" wcale tego odbiorcy nie zapowiada. Podobne podejście metodologiczne, jak Bitiego (i Rapackiej), odnaleźć można też w kilkutomowej pracy zatytułowanej Pojmovnik ruske avangarde (powstała ona w katedrze komparatystyki na uniwersytecie w Zagrzebiu w latach osiemdziesiątych pod red. A. Flaker, D. Ugrešić, wyd. 1984-87). $\mathrm{Z}$ nią wiązać należy pojawienie się w języku chorwackim neologizmu ,pojęciownik" i z niej właśnie zaczerpnięty został tytuł Bitijego.

Kolejne określeniem $\mathrm{z}$ tytułu, które należy sprecyzować i wyjaśnić, to współczesność. Jest ona głównym kryterium wyboru przedstawianych pojęć. Najważniejszym wyznacznikiem współczesności teorii literatury jest dla Bitijego proces autorefleksji, jaki zaczyna towarzyszyć, czy nawet współtworzyć tę dziedzinę od czasu przełomu antypozytywistycznego, czy jak pisze się o tym w chorwackiej obszarze, w schylkowej fazie paradygmatu modernistycznego. Współczesna teoria literatury, to taka teoria, która ma wątpliwości, co do swojego statusu i pozycji wśród innych nauk, przede wszystkim co do relacji wobec samej literatury. Dosłowny przekład przymiotnika w tytule („teoria literacka”) zgodny z intencją samego autora wskazuje właśnie na dwuznaczność, która powstaje po przekroczeniu tradycyjnej granicy podziału pomiędzy literaturą a teorią. Wspólczesna teoria literatury do tego stopnia nie jest pewna swojej autonomii, że nie waha się samą siebie nazywać "literacka". Dodanie natomiast do tytułu w drugim wydaniu określenia ,kulturowy”, jak w przedmowie wyjaśnia autor, to nie tylko sygnał rozszerzenia pola zainteresowań, ale podkreślenie określonej tendencji we współczesnej teorii, jej samouświadomienia sobie własnego kulturowego zakorzenienia i etyczno-politycznego wymiaru:

Każda teoria, czy tego chce czy nie, przynależy do określonej przestrzeni kulturowej, gdzie określone wpierw zostaje co w ogóle znaczy kultura. Każda więc teoria jest kulturowa w tym sensie, że wyklucza inną teorię jako niekulturową, niegodną uwagi i zajęcia się nią, a poprzez to właśnie włącza wspomniany wymiar polityczno-etyczny. Współczesna teoria zajmuje się literaturą i kulturą z pełną świadomością tego, ze obie one już wcześniej zajęły się nią samą impregnując jej horyzonty, miejsce, z jakiego przemawia, i słowa, których używa. [P II, s. VI]

Dzięki takiemu rozumieniu współczesności, literackości i kulturowości, Bitijemu udaje się wytlumaczyć zastosowaną w „pojęciowniku” metodę opowiadania o teoriach w formie krótkich narracji o życiu, karierze, a niekiedy i śmierci pojęć, które powstały w ciągu ostatniego wieku dla potrzeb dyskursu o literaturze, a zarazem ostrzec przed różnymi niebezpieczeństwami, od których sam nie jest wolny. 


\section{System}

„Pojęciownik” w najnowszej wersji zawiera około dwustu pięćdziesięciu haseł. Przy każdym haśle wymienione są obcojęzyczne odpowiedniki (tym samym wskazane zostaje pochadzenie i zakres występowania danego pojęcia). Właściwa "definicja”w cudzysłowie, gdyż zgodnie z nieobowiązującym w "pojęciowniku” normatywizmem prezentacje przypominają raczej kruche wielogłosowe konstrukcje, aniżeli dokładne opisanie i nazwanie rzeczy po imieniu - najczęściej składa się z przytoczonych lub zacytowanych różnych koncepcji i poglądów, jest swojego rodzaju streszczeniem dyskusji toczonych na dany temat $w$ literaturoznawstwie. Jest szkicem, krótkim artykułem, opowieścią.

W nowym wydaniu usprawniona jest też marszruta poruszania się po labiryncie pojęciownika. W wydaniu pierwszym oprócz wykazu pojęć i nazwisk, wszystkie odnośniki i polączenia pomiędzyhasłowe zaznaczone były w tekście, pod hasłem lub poprzez gwiazdeczkę. Teraz zrezygnowano $z$ tradycyjnych odsyłaczy $i$ indeksów na rzecz oddzielnego wykazu pojęć i pokrewnych zagadnień umieszczonego na końcu książki, tworzącego jakby mapę labiryntu. Sporo „definicji” zostało przeformułowanych (nowe partie tekstu sygnalizuje kursywa), wskutek czego powstał interesujący i wymowny palimpsest. Autor zrezygnował również $z$ wymieniania $w$ haśle tytułów przywoływanych i cytowanych prac, ograniczając się do zasygnalizowania ich datą wydania - resztę można odtworzyć na podstawie bibliografii (liczy ona kilkadziesiąt stron) - co nadało narracji bardziej wartkie tempo. Odstąpił także od każdorazowego zaznaczania nurtu, tradycji, narodowości czy „pokrewieństw” wspominanego badacza, zostawiając samo nazwisko. Zabiegi te oczyścily tekst ze schematycznych formułek, jednocześnie specjalizując go jeszcze bardziej. W „pojęciowniku” nie ma też miejsca na biografie. Podstawowy schemat prezentacji w drugim wydaniu nie uległ jednak zmianie - wyznaczają go porządek alfabetyczny i chronologia ( $w$ obrębie samych haseł). Są to jedyne obiektywizujące zasady zastosowane w tekście, reszta to różne, często sprzeczne, atakujące się czy dialogujące ze sobą głosy.

\section{Pojęcia}

W pojęciowniku można wyróżnić kilka rodzajów haseł. Po pierwsze, nie zabrakło pojęć, wbrew zadeklarowanej "współczesności”, znanych z tradycyjnej poetyki, o ile oczywiście stały się one przedmiotem zainteresowania współczesnych teoretyków i badaczy. Pojęcia takie, jak alegoria, metafora, symbol, dialog, fabuła, narrator czy bohater, zyskały przecież $w$ dwudziestym wieku zupełnie nowe znaczenie i rozumienie. To pojęcia odziedziczone. Przy nich lepiej widoczna staje się różnica pomiędzy „pojęciownikiem” Bitijego a słownikami normatywnymi. Zamiast szlifować definicje Biti opowiada o różnych sposobach widzenia i wartościowania tych pojęć, o definicjach, jakimi były opatrywane. Przywoluje tradycyjne koncepcje i w skrócie pokazuje kolejne etapy przekształceń i momenty przełomowe. Podobnie rzecz ma się z takimi kluczowymi pojęciami jak literatura, nauka o literaturze, historia literatury, dzieło, autor, w których "definicjach" można by się spodziewać niebezpośrednich choćby deklaracji ze strony autora. Znów jednak mamy do czynienia ze zbiorem różnych stanowisk, które układają się w dynamiczną opowieść. Jak pisze Biti w „portrecie” literatury: „Pojęcie, które we współczesnej teorii literatury zgubiło swoje oczywiste 
znaczenie, wskutek czego, razem $z$ innymi podobnymi "naturalnymi pojęciami" [podkreślenie M.K.] przestało być niedostępne dla analitycznych dociekań [P I, s. 173].

Kolejna grupa pojęć to hasła historyczno-metodologiczne: terminy dotyczące szkół, formacji i kierunków w literaturoznawstwie, zarówno tym nowszym (choć już klasycznym), jak i tym sięgającym korzeniami wieku XIX, takich jak formalizm, strukturalizm, hermeneutyka, historyzm, szkoła praska, szkola tartuska, poststrukturalizm, postmodernizm, dekonstrukcja, postkolonialna teoria, postmodernizm, poststrukturalizm, krytyka fenomenologiczna, marksistowska, psychoanalityczna, feministyczna, etc. Tutaj Biti za każdym razem stara się pokazać wzajemne wpływy, zależności, inspiracje czy reakcje pomiędzy formacjami. Nie daje w każdym razie zwykłych streszczeń, ukazuje koncepcje w procesie przemian, w różnych fazach, wydobywając ich różne aspekty, wewnętrzne napięcia i potencje. Sam też przyznaje, że niegdysiejsze niemożliwe do przekroczenia różnice, ustąpiły miejsca punktom wspólnym, a śledzenie wszystkich ostatnich rewizji, tendencji, zwrotów poglądów i stanowisk, sprawiło, że wiele $z$ tej grupy haseł sformułowal na nowo.

Pojęcia wywodzące się z poszczególnych szkół i doktryn literaturoznawczych, które weszły do powszechnego języka teoretycznego, tworzą kolejną grupę haseł. Obejmuje ona całe strukturalistyczne i semiotyczne nazewnictwo, także językoznawcze, dekonstrukcjonistyczne, derridiańskie słowa-klucze, oraz pojęcia związane z koncepcjami poszczególnych badaczy z różnych faz ich twórczości. Zapożyczenia, kalki, które często w polskim literaturoznawstwie nie istnieją bądź przyjmowane są z dużą nieufnością, Biti wprowadza do chorwackiego lekką ręką, umyślnie i jakby na przekór purystycznym tendencjom, które zwłaszcza w latach dziewięćdziesiątych dominowały $w$ myśleniu o języku chorwackim ( $w$ tym wypadku nie bez znaczenia pozostawał kontekst polityczny). Z pewnością dobór pojęć może budzić zastrzeżenia lecz trudno zarzucić jakieś większe uchybienia. Tutaj zresztą ujawniają się najsilniej uwarunkowania wyborów Bitijego. Za przykład niech posłużą terminy Genette'a. W polskiej mowie o literaturze najczęściej spotkać można te $z$ Palimsestów, podczas gdy do obiegu chorwackiego weszły przede wszystkim terminy wywodzące się z teorii narratologicznych (narratologia, fokalizacja, analepsa, prolepsa, anachronia, izochronia), używane na przykład w badaniach literatury dawnej.

Swojego rodzaju grupę tworzyć mogą pojęcia, które stały się punktami wspólnymi i kluczowymi zarazem dla współczesnej humanistyki, czerpane $z$ innych dziedzin naukowych, jak socjologia, psychologia, etnologia, językoznawstwo czy teoria komunikacji (archetyp, mit, język, gramatyka, historia, ikona, informacja, instytucja, system etc.). Ich "definicje" to także przedstawienia różnych sposobów rozumienia i zastosowania.

W drugim wydaniu pojawiają się także hasła: etyka, ciało, tożsamość, pamięć, wartość, które wyraźnie pokazują, jak zmieniły się i w jakim kierunku podążają zainteresowania najnowszej teorii literatury.

Proporcje, jakie zachowuje Biti, wyróżniając jedne zjawiska, drugie zaś podporządkowując innym, sprawić mogą, że nie uda nam się trafić wprost do jakiegoś zagadnienia, ale może właśnje takimi drogami przyszło się poruszać współczesnej teorii. Poza tym nie mamy przecież do czynienia ze słownikiem terminów sztuk pięknych, gdzie pod każdym hasłem ukryty jest konkretny desygnat. W, pojęciowniku" Bitijego poprzez labirynt encyklopedii (pojęć, odnośników, powtórzeń, odbić, 
skrótów, przytoczeń i odwołań) ukazana zostaje cała złożoność, współzależność i uwikłanie wspólczesnej teorii. Forma encyklopedii, paradoksalnie wykorzystana do prezentacji między innymi koncepcji, które podważają jej „obiektywność”, stała się ksztaltem który doskonale odbija opisywany przedmiot. Wielogłosowość pojęciownika to sposób na ukazanie względności teorii, gdyż żaden z głosów nie zajmuje uprzywilejowanego miejsca. Nie wynika jednak z tego, że prawda nie istnieje, „a jedynie że

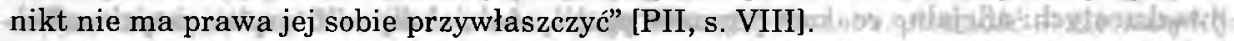

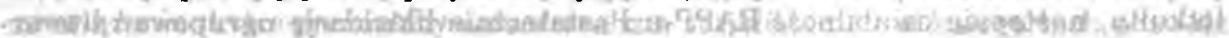

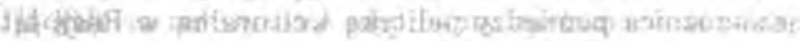
Malgorzata Kryska

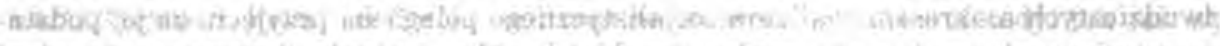

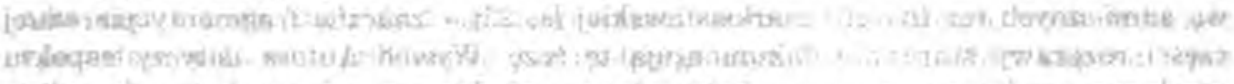
Realizm socjalistyczny - spór o metode

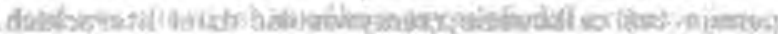

E. Możejko, Realizm socjalistyczny.

Teoria. Rozwój. Upadek, Kraków: Universitas 2001, 314 ss.

Książka Edwarda Możejki była przed ćwierćwieczem jedną z pierwszych poważnych publikacji poświęconych realizmowi socjalistycznemu, podejmujących to zagadnienie w tak szerokim zakresie. Ukazała się w 1977 roku niemal równocześnie w Niemczech, Danii i Norwegii. Jej autor, polski emigrant, po krótkim pobycie w Danii osiadl na stałe w Edmonton, podejmując pracę jako slawista i komparatysta w University of Alberta. Zasłużony dla rozwoju slawistyki i komparatystyki między innymi jako redaktor naczelny „Canadian Slavonic Papers”, przez kilku ostatnich lat pracowal na Uniwersytecie Śląskim, ostatnio zaś na Uniwersytecie Jagiellońskim. Odnowionym $w$ ciągu tych lat kontaktom $z$ polską slawistyką należy najpewniej zawdzięczać pojawienie się polskiej wersji jednej z jego najważniejszych rozpraw studium o realizmie socjalistycznym.

Jest to problematyka podejmowana w Polsce od dawna - posiada ona w naszym kraju bogatą i poważną literaturę . Książka Możejki przynosi jednak analizę jej aspektów dotąd nie podejmowanych lub opisywanych jedynie szczątkowo. Autor określa swoje zadanie wprost:

[...] chodzi po pierwsze, o możliwie najpełniejsze wyjaśnienie tych procesów spoleczno-politycznych i kulturalnych, które doprowadziły do powstania takiej właśnie koncepcji literatury i sztuki, jaką jest realizm socjalistyczny, a po drugie o wyjaśnienie jego zasad teoretycznych [s. 19-20].

Pierwsze $\mathrm{z}$ tych zadań wydaje mi się spełnione jedynie w niewielkim stopniu, drugie zaś stanowi najistotniejszą zawartość rozprawy. $W$ istocie bowiem wywód Możejki poświęcony jest, poza niewielkimi fragmentami, opisowi teoretycznej samoświadomości realizmu socjalistycznego i tak naprawde Autor powinien był zatytułować swoje studium: Teoria realizmu socjalistycznego: powstanie, rozwój, upadek.

${ }^{6}$ Ewolucję poglądów polskich badaczy w tym zakresie omawiam w artykule: Realizm socjalistyczny $w$ polskiej refleksji naukowej (przeglad), w: 50 lat polskiej rusycystyki literaturoznawczej, red. P. Fast, B. Stempczyńska, Katowice, 2000, s. 78-86. 